\title{
Humid Air Plasma Treatment of Birnessite Surface: Application to the Removal of Cochineal Red
}

\author{
Wafa Chouchene, Nizar Bellakhal \\ UR de Catalyse, Electrochimie de Nanomatériaux et Leurs Applications et de Didactique, Institut National des \\ Sciences Appliquées et de Technologie (INSAT), Tunis, Tunisie \\ Email: wafachouchene7@yahoo.fr
}

Received 8 October 2015; accepted 17 November 2015; published 20 November 2015

Copyright $@ 2015$ by authors and Scientific Research Publishing Inc.

This work is licensed under the Creative Commons Attribution International License (CC BY). http://creativecommons.org/licenses/by/4.0/

(c) (i) Open Access

\section{Abstract}

The thin layers of birnessite $\left(\mathrm{Mn}_{7} \mathrm{O}_{13} \cdot 5 \mathrm{H}_{2} \mathrm{O}\right)$ are exposed to reactive species gliding arc plasma in humid air, which induces the treatment of the thin layers surface. Plasma treatment thin layer of birnessite was used for the degradation of Cochineal Red. The experimental results showed that 95\% of the CR solution was completely decolorized by thin layer of birnessite treated by plasma compared to $80 \%$ of the same solution after interaction of thin layer of birnessite untreated. The decay kinetics always follows a pseudo-first order reaction. The application of the humid air plasma for the surface treatment of thin layers of birnessite improves the efficiency of treatment for Cochineal Red degradation.

\section{Keywords}

Humid Air Plasma, Surface Treatment, Thin Layers of Birnessite, Cochineal Red, Degradation

\section{Introduction}

Dyes production industries which used dyes and pigments generated wastewater, characteristically high in color and organic content [1]. Azo dyes represent the largest class of dyes, and a part of them are suspected to be carcinogenic [2]-[4]. Environmental pollution by organic azo dyes presents a severe ecological problem that leads to the necessity of treatment by the fact that most of these dyes are difficult to degrade by traditional techniques [5]-[9]. But developing new environmentally methods to degrade organic pollutants in wastewater seems always interesting. In this aim, we have shown the successful possibility to use birnessite thin films to decolorized solutions containing azo dyes [10]. The birnessite $\left(\mathrm{Mn}_{7} \mathrm{O}_{13} \cdot 5 \mathrm{H}_{2} \mathrm{O}\right)$ was considered as the most interesting manganese 
oxide because of its high absorption capacity and its redox properties [10]-[15]. These results encouraged us to investigate to use thin films of birnessite treated initialy by an humid air plasma generated by a gliding arc, in the degradation of Cochineal Red (2-hydroxy-1-(4-sulfonate-1-naphtylazo)-6,8-naphtalène disulfonate trisodium). A humid air plasma is characterized by the occurrence of a large number of excited species which confers on them an enhanced reactivity involved in numerous plasma treatments of materials. These chemical properties are classified into acid-base and oxidation-reduction properties. This work was performed with a humid air plasma gas produced by the gliding arc proposed by Lesueur et al. [16]. Several processes such as ionization, dissociation by electron impact, and attachment phenomena take place in the plasma [17]. The spectroscopic investigation of the emission bands of gliding arc discharge in humid air in the 230 - $650 \mathrm{~nm}$ range showed the occurrence of the radicals $\mathrm{NO}^{-}$and $\mathrm{OH}^{-}$as the main species present in the plasma [18]. These activated species show an enhanced chemical reactivity and particular some of them behave as strong oxidizing agents $\left(\mathrm{OH}^{*}, \mathrm{H}_{2} \mathrm{O}_{2}, \mathrm{O}_{3}\right.$, $\mathrm{NO}_{\mathrm{x}}, \mathrm{NO}^{*}$ ) [19]. This paper is devoted of degradation of Cochineal Red by thin layers of birnessite after changing its oxidizing properties by humid air plasma.

\section{Experimental}

\subsection{Plasma Device}

An electric arc was created between two diverging aluminium electrodes raised to a convenient voltage. The alternative current generator delivered a suitable energy $(100 \mathrm{~mA} ; 9000 \mathrm{~V})$. A gas flow along the axis of the reactor blew the arc and made it glide along the electrodes before breaking. After breaking, a new arc formed and the cycle resumed. The air provided by an air compressor was saturated with water by bubbling in a Durand flask before entering the reactor through a nozzle (diameter $0.99 \mathrm{~mm}$ ). The arc is pushed away from the ignition point by the feeding gas flow and sweeps along the maximum length of the electrode gap and forming a large plasma plume, so that it licks the surface of thin layer of birnessite. The treatment is done in open system fixing the functioning parameters. The gas flow is fixed at $\mathrm{Q}=650 \mathrm{~L} \cdot \mathrm{h}^{-1}$, the divergence between the electrodes $\mathrm{e}=3.5$ $\mathrm{mm}$ and the distance between the electrodes and the surface of thin layers of birnessite $\mathrm{d}=5 \mathrm{~cm}$. The brass foils were exposed to the plasma flux as shown in Figure 1.

The $\mathrm{OH}^{-}$species is the main responsible for strong oxidizing character of the discharge [20] [21]. The hydroxyl radical is a very reactive species having an oxidation potential of $\mathrm{E}^{\circ}\left(\mathrm{OH}^{*} / \mathrm{H}_{2} \mathrm{O}\right)=2.85 \mathrm{~V} / \mathrm{NHE}$ [22]. On the other hand, the $\mathrm{NO}^{\circ}$ radical leads to the formation of $\mathrm{NO}_{2}$, nitrite and nitrate ions according to the following overall reactions [23]:

$$
\begin{aligned}
& \mathrm{H}_{2} \mathrm{O}+\mathrm{e}^{-} \rightarrow \mathrm{OH}^{\cdot}+\mathrm{H}^{\cdot}+\mathrm{e}^{-} \\
& \mathrm{HO}_{2}{ }^{\cdot}+\mathrm{HO}_{2} \cdot \rightarrow \mathrm{H}_{2} \mathrm{O}_{2}+\mathrm{O}_{2} \\
& \mathrm{NO}+{ }^{\cdot} \mathrm{OH} \rightarrow \mathrm{NO}_{2}+\mathrm{H}^{\cdot} \\
& \mathrm{NO}_{2}+\mathrm{HO}_{2} \rightarrow \mathrm{HNO}_{2}+\mathrm{O}_{2} \\
& 2 \mathrm{OH}^{\cdot} \rightarrow \mathrm{H}_{2} \mathrm{O}_{2}
\end{aligned}
$$

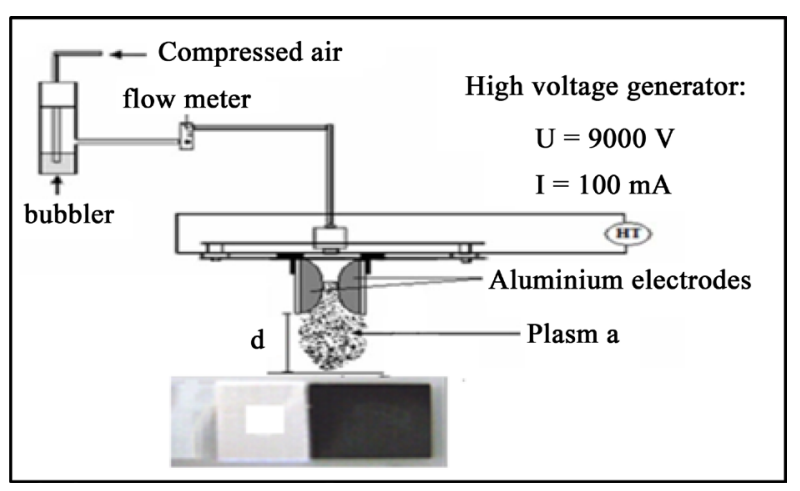

Figure 1. Schema of a gliding arc device: HT = 9000V; Q $=650 \mathrm{~L}^{-1} \mathrm{~h}^{-1} \mathrm{~d}=5 \mathrm{~cm} ; \mathrm{e}=3.5 \mathrm{~mm} ; \phi=0.99 \mathrm{~mm}$. 


\subsection{Materials and Methods}

The azo dye Cochineal Red was obtained from Sigma-Aldrich and has a purity of 99\%. The molecular structure of Cochineal Red $\left(\mathrm{C}_{20} \mathrm{H}_{11} \mathrm{~N}_{2} \mathrm{Na}_{3} \mathrm{O}_{10} \mathrm{~S}_{3}\right)$ was given in Figure 2.

A classical electrochemical cell with three electrodes was used. The thin layers of birnessite were electrodeposited by chronoamperometry at $\mathrm{E}=0.6 \mathrm{~V} / \mathrm{MSE}$, in neutral aerated solution containing sodium sulphate and manganese sulphate [10]. The electro-oxidation of $\mathrm{Mn}^{2+}$ in neutral aerated sulfate solution leads to the formation of birnessite $\left(\mathrm{Mn}_{7} \mathrm{O}_{13} \cdot 5 \mathrm{H}_{2} \mathrm{O}\right)$ [10] [24].

The Cochineal Red concentrations in the solution were determinated by an UV-vis spectrophotometer (Backman). Chemical oxygen demand (COD) measurements were carried out using the French AFNOR norm. The organic matter was oxidized by potassium dichromate $\mathrm{K}_{2} \mathrm{Cr}_{2} \mathrm{O}_{7}$ under energetic conditions. The temperature of the solution was raised $170^{\circ} \mathrm{C}$ over $2 \mathrm{~h}$. The excess of potassium dichromate was measured out by Mohr salt titration. COD was calculated from the expression:

$$
\operatorname{COD}\left(\mathrm{mg} \mathrm{O}_{2} / \mathrm{L}\right)=8000 \times\left(\mathrm{V}_{(\mathrm{MS}) \text { blank }}-\mathrm{V}_{(\mathrm{MS}) \text { sample }}\right) \times \mathrm{N}_{(\mathrm{MS})} / \mathrm{V}_{0}
$$

where $\mathrm{V}_{(\mathrm{MS}) \text { blank }}$ and $\mathrm{V}_{(\mathrm{MS}) \text { sample }}$ are the volumes of standard Mohr salt solution used for the blank and the sample respectively, $\mathrm{N}_{(\mathrm{MS})}$ is the normality of the Mohr salt solution, and $\mathrm{V}_{0}$ is the volume of the sample.

\section{Results and Discussions}

\subsection{Treatment of Birnessite Surface by Humid Air Plasma}

Like most manganese oxides, birnessite oxidizes organic pollutants via an electronic exchange that occurs at the surface (Shin Buzgo et al.) [25] [26]. Birnessite $\left(\mathrm{Mn}_{7} \mathrm{O}_{13} \cdot 5 \mathrm{H}_{2} \mathrm{O}\right)$ contains manganese with two degrees of oxidation $\left(\mathrm{Mn}^{4+}\right.$ and $\left.\mathrm{Mn}^{3+}\right)$ but $\mathrm{Mn}^{4+}$ most oxidizing species which is supposed to react preferentially with pollutants [10]. In general, organic pollutants react with the manganese oxides via Mn(IV) ions which are reduced to Mn(II) in one step [27]-[29] or via a compound $\mathrm{Mn}$ (III) [30]. The determination of the average oxidation degree of manganese allows as to evaluate the $\mathrm{Mn}(\mathrm{III}) / \mathrm{Mn}(\mathrm{VI})$ of the different forms of manganese existing in the sheets of thin layers of birnessite. To determine the average oxidation degree of manganese, we use the titration potentiometry method allong with sodium pyrophosphate and Mohr's salt [31]. The average oxidation degree of manganese of thin layers of birnessite untreated and treated by humid air plasma is set in Table 1.

As shown in Table 1, the sheets of thin layers of birnessite untreated are formed from a mixture of $\mathrm{Mn}^{4+}$ and $\mathrm{Mn}^{3+}$ while proportions are respectively $60 \%$ and $40 \%$ [10] [31]. However, the sheets of thin layers of birnessite treated by humid air plasma are more loaded with $\mathrm{Mn}^{4+}$ ions while proportions are $80 \% \mathrm{Mn}^{4+}$ and $20 \% \mathrm{Mn}^{3+}$. Therefore, thin layers of birnessite obtained under these conditions are more oxidizing and loaded with $\mathrm{Mn}^{4+}$ ions. This is in good agreement with improved degradation of dyes [31].

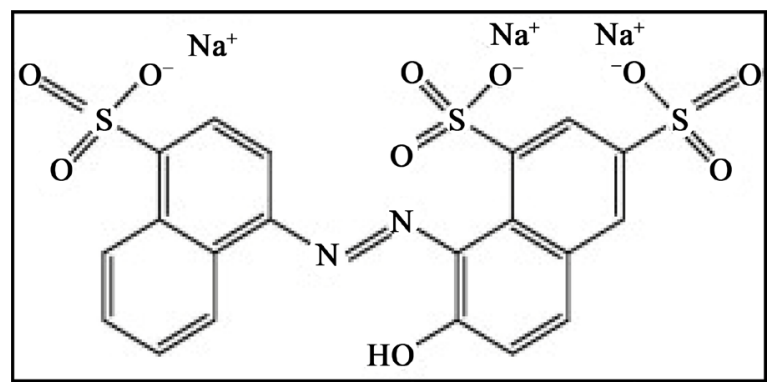

Figure 2. Cochineal red structure.

Table 1. Average degree of oxidation of manganese of birnessite untreated and treated.

\begin{tabular}{ccc}
\hline Average degree of oxidation & $\% \mathrm{Mn}^{3+}$ & $\% \mathrm{Mn}^{4+}$ \\
\hline Birnessite untreated & $40 \%$ & $\mathbf{6 0 \%}$ \\
Birnessite treated & $\mathbf{2 0 \%}$ & $\mathbf{8 0} \%$ \\
\hline
\end{tabular}




\subsection{Removal of Cochineal Red by Thin Layers of Birnessite}

Figure 3 shows the UV-Visible spectra obtained during interaction, between one thin layer of birnessite untreated and a solution of CR during $24 \mathrm{~h}$.

The $512 \mathrm{~nm}$ peak of intensity of the CR solution decreases as treatment time increases implying that the majority of Cochineal Red molecules are destroyed. After $24 \mathrm{~h}$ of interaction, the peak at $512 \mathrm{~nm}$ was decreased and the solution was totally discolored $80 \%$. These results proves the efficiency of the thin layers of birnessite to the degradation of dyes [10] [32]-[34].

\subsection{Removal of Cochineal Red by Thin Layers of Birnessite Treated by Humid Air Plasma}

Figure 4 shows the UV-Vis spectra obtained after the interaction between CR solution and thin layer of birnessite that has been exposed firstly to the discharge of humid air plasma. The $512 \mathrm{~nm}$ peak of intensity of the treated solution decreases as treatment time increases implying that the majority of Cochineal Red molecules are destroyed.

After $24 \mathrm{~h}$ of interaction, the peak at $512 \mathrm{~nm}$ was decreased and solution was totally discolored $95 \%$ with a thin layer of birnessite treated by humid air plasma compared to $80 \%$ with a thin layer of birnessite untreated.

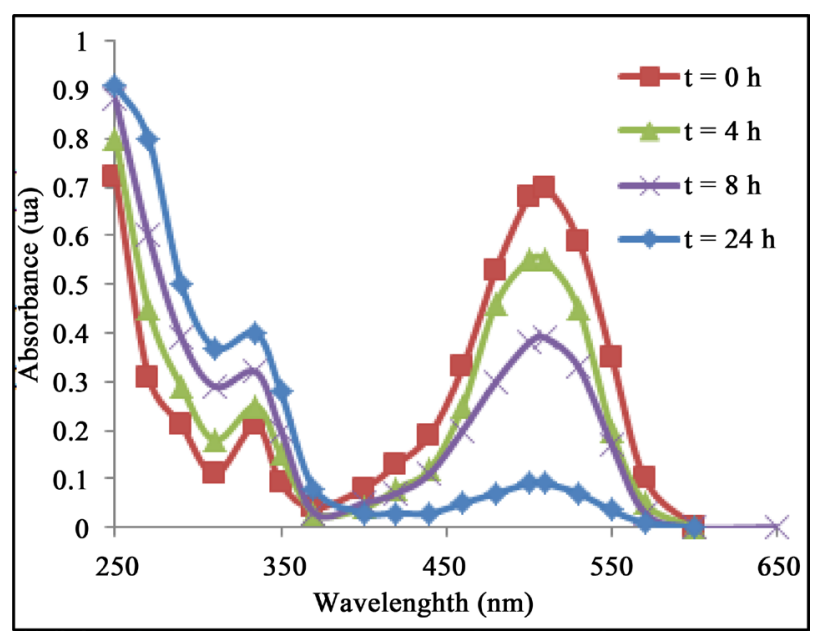

Figure 3. UV-Visible spectra of cochineal red solution in interaction with a thin layer of birnessite untreated $\left(\mathrm{C}=8.25 \times 10^{-6} \mathrm{~mol} \cdot \mathrm{L}^{-1}, \mathrm{~V}=10 \mathrm{ml}, \mathrm{pH}=3\right)$.

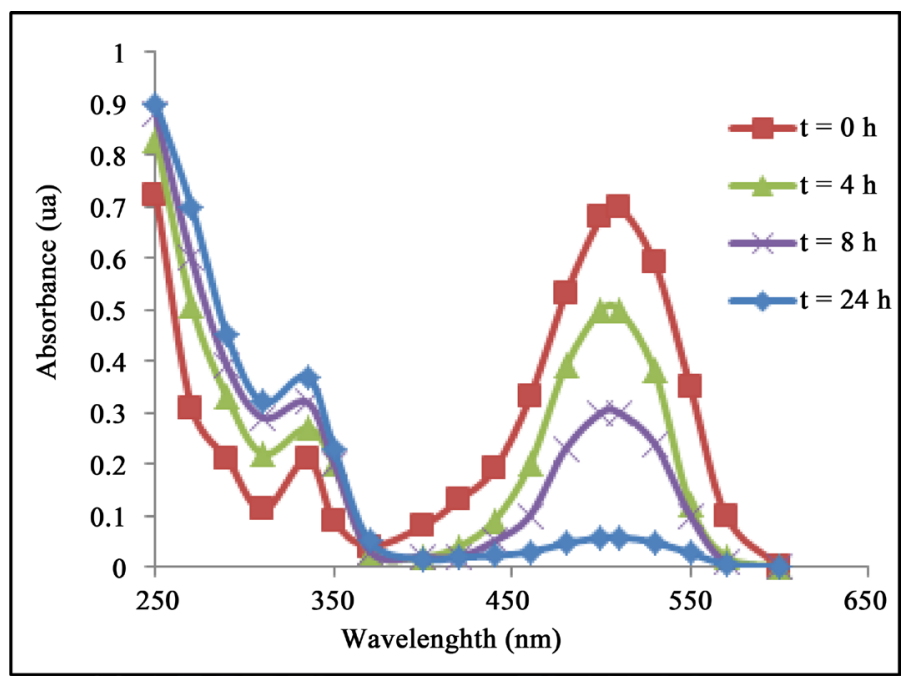

Figure 4. UV-Visible spectra of cochineal red solution in interaction with thin layer of birnessite treated by humid air plasma $\left(\mathrm{C}=8.25 \times 10^{-6} \mathrm{~mol} \cdot \mathrm{L}^{-1}, \mathrm{~V}=10 \mathrm{ml}, \mathrm{pH}=3, \mathrm{Q}=650 \mathrm{~L} \cdot \mathrm{h}^{-1} ; \mathrm{d}=5 \mathrm{~cm}\right)$. 
These results confirm the very important effect of thin layer of birnessite after changing its oxidizing properties by humid air plasma on the degradation of Cochineal Red.

\subsection{Kinetic Studies of the Degradation of Cochineal Red}

Our interest is turned to study the kinetic order of the degradation of Cochineal Red. The kinetic of CR discoloration with birnessite thin layer was studied with concentration of CR $8.25 \times 10^{-6} \mathrm{~mol} \cdot \mathrm{L}^{-1}$. Using the dye concentration-absorbance relationship (Beer-Lambert's law: A = Cel) the pseudo-first order kinetic model can be written as: $\operatorname{Ln}\left(\mathrm{A}_{0} / \mathrm{A}\right)=\mathrm{K}_{\mathrm{app}}$.t.

As shown in Figure 5, the degradation reaction follows pseudo-first order kinetic with correlation coefficient $\mathrm{R}^{2}$ value of $0.993-0.980$ in good agreement with kinetic degradations of organic pollutants by manganese oxides [10] [35]-[37]. The degradation rates are high showing the very important effect of birnessite on the degradation of Cochineal Red especially with birnessite treated by humid air plasma.

\subsection{Influence of Cochineal Red Concentration}

The effect of CR concentration was evaluated in the range that varied between $8.25 \times 10^{-6} \mathrm{~mol} \cdot \mathrm{L}^{-1}$ and $3.3 \times$ $10^{-5} \mathrm{~mol} \cdot \mathrm{L}^{-1}$. Figure 6 shows the discoloration efficiency (\%), calculated versus time for various concentrations

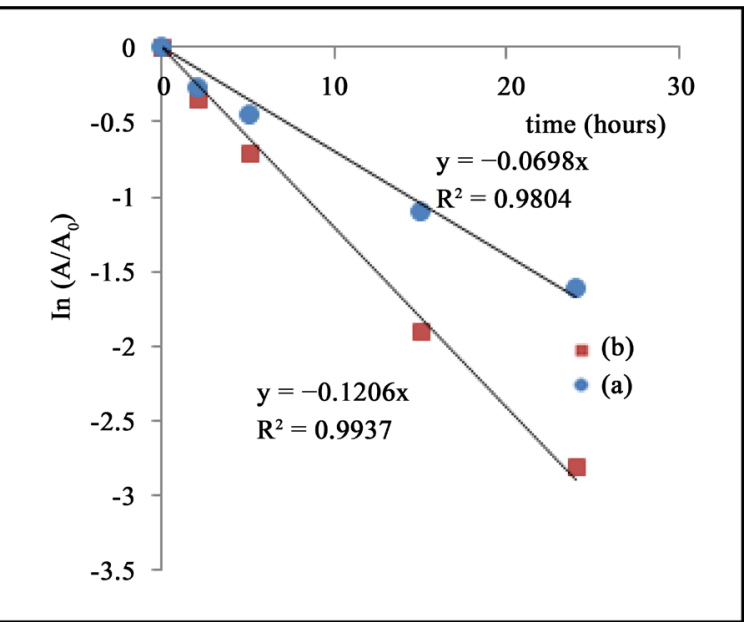

Figure 5. Kinetic order of the degradation of cochineal red with a thin layer of birnessite (a) Untreated and (b) Treated by humid air plasma. $\left(\mathrm{C}=8.25 \times 10^{-6} \mathrm{~mol} \cdot \mathrm{L}^{-1}, \mathrm{~V}=10 \mathrm{ml}, \mathrm{pH}=3, \mathrm{Q}=650 \mathrm{~L} \cdot \mathrm{h}^{-1} ; \mathrm{d}=5 \mathrm{~cm}\right)$.

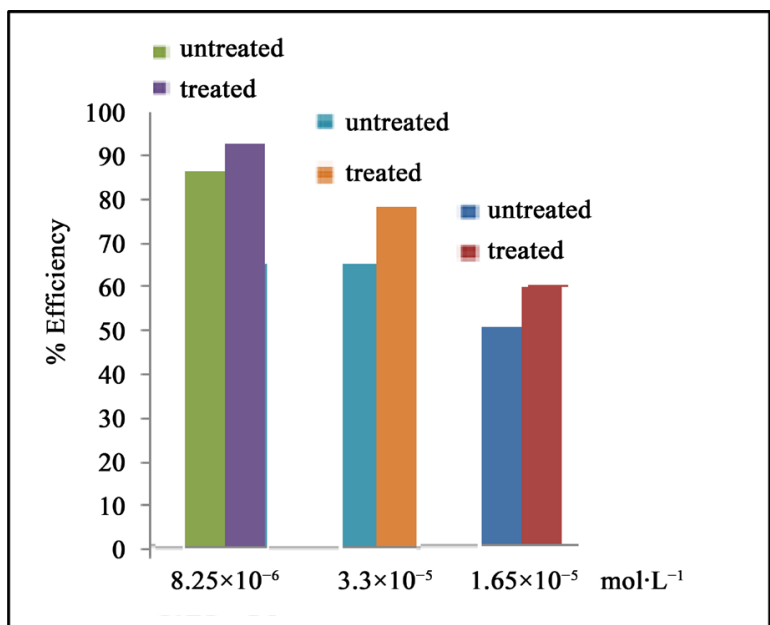

Figure 6. Influence of the concentration of CR solutions on the effectiveness of treatment with a thin layer of birnessite untreated and treated by humid air plasma $\left(\mathrm{V}=10 \mathrm{ml}, \mathrm{pH}=3, \mathrm{Q}=650 \mathrm{~L} \cdot \mathrm{h}^{-1} ; \mathrm{d}=5 \mathrm{~cm}\right)$. 


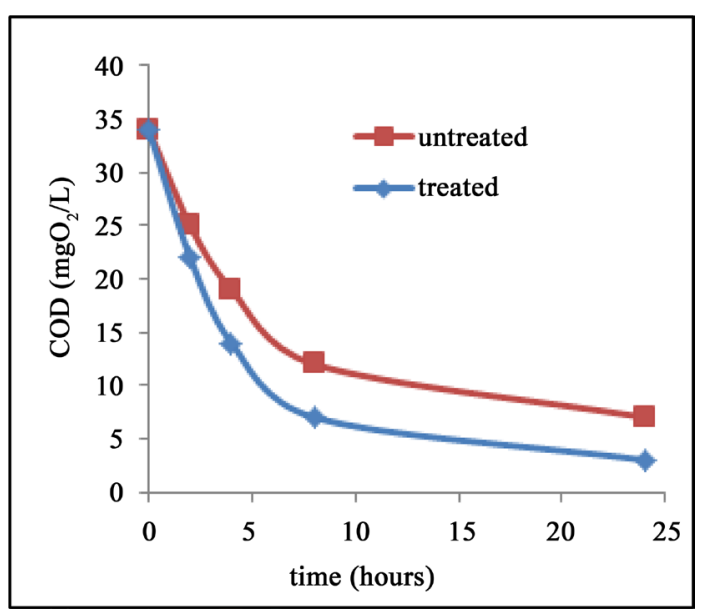

Figure 7. Evolution of Chemical oxygen demand (COD) of cochineal red in interaction with a thin layer of birnessite untreated and treated by humid air plasma $\left(C=8.25 \times 10^{-6} \mathrm{~mol} \cdot \mathrm{L}^{-1}, \mathrm{~V}=200 \mathrm{ml}, \mathrm{pH}=3, \mathrm{Q}=650 \mathrm{~L} \cdot \mathrm{h}^{-1} ; \mathrm{d}=5 \mathrm{~cm}\right)$.

of CR.

Results obtained showed that, when the initial CR concentration is $8.25 \times 10^{-6} \mathrm{~mol} \cdot \mathrm{L}^{-1}$ the treatment is effective at about $95 \%$ for CR solution in interaction with thin layer of birnessite treated by humid air plasma and about $80 \%$ for thin layer of birnessite untreated. However at a concentration of $3.3 \times 10^{-5} \mathrm{~mol} \cdot \mathrm{L}^{-1}$, only $60 \%$ of the color disappeared even after $24 \mathrm{~h}$ for CR solution in interaction with thin layer of birnessite treated by humid air plasma and about $50 \%$ for thin layer of birnessite untreated. The results show that the effectiveness of treatment increased with CR solution in interaction with thin layer of birnessite treated by humid air plasma and CR discoloration increased with increase the initial CR concentration.

\subsection{Mineralization Efficiency}

Mineralization of treated Cochineal Red solutions are followed by measuring the chemical oxygen demand (COD) values to evaluate the organic carbon content of the solution. Electrolysis of initial Cochineal Red solution leads to a gradual decrease in chemical oxygen demand (COD) with electrical charge Q consumed, indicating the mineralization. The Figure 7 shows that the mineralization process reached a ratio $80 \%$ at $24 \mathrm{~h}$ for thin layer of birnessite untreated compared to 95\% for thin layer of birnessite treated by humid air plasma. The degradation of Cochineal Red is not only a breaking of the azo band, but also degradation of the aromatic rings [10].

It is also to be mentioned that final degradation products were mineral ions such $\mathrm{NH}_{4}^{+}, \mathrm{NO}_{3}^{-}$and $\mathrm{SO}_{4}^{2-}$ according to the substituent groups included in the initial molecule, as well as $\mathrm{CO}_{2}$ and $\mathrm{H}_{2} \mathrm{O}$ [10] [38] [39].

\section{Conclusion}

This paper is devoted to the surface treatment of thin layer of birnessite by an humid air plasma, in fact, it has been well established that oxidative degradation of organic matter by thin layers of birnessite is via a surface mechanism [10] [40] [41]. Furthermore, this surface treatment has been increasing significantly the efficiency of the treatment of the Cochineal Red solution from $80 \%$ to $95 \%$. These experimental results are important because Cochineal Red is extensively employed in many industries. So, birnessite thin layer treated by humid air plasma appears as a very interesting material for the development of a simple and ecological method applied to the remediation of wastewater containing Cochineal Red.

\section{References}

[1] Guyer, G.T. and Ince, N.H. (2003) Degradation and Toxicity Reduction of Textile Dyestuff by Ultrasound. Ultrasonics Sonochemistry, 10, 235-240. http://dx.doi.org/10.1016/S1350-4177(03)00089-0

[2] Sauer, T., Nero, G.C., Jose, H.J. and Moreira, R.F.P.M. (2002) Kinetics of Photocatalytic Degradation of Reactive Dyes in a $\mathrm{TiO}_{2}$ Slurry Reactor. Journal of Photochemistry and Photobiology A: Chemistry, 149, 147-154. 
http://dx.doi.org/10.1016/S1010-6030(02)00015-1

[3] Cisneros, R.L., Espinoza, A.G. and Litter, M.I. (2002) Photodegradation of an Azo Dye of the Textile Industry. Chemosphere, 48, 393.

[4] Karkmaz, M., Puzenat, E., Guillard, C. and Herrmann, J.M. (2004) Photocatalyticdegradation of the Alimentary Azo Dye Amaranth: Mineralization of the Azo Group to Nitrogen. Applied Catalysis, 51, 183.

[5] Brillas, E., Boye, B., Sirés, I., Garrido, J.A., Rodríguez, R.M., Arias, C., Cabot, P.L. and Comninellis, C. (2004) Electrochemical Destruction of Chlorophenoxy Herbicides by Anodic Oxidation and Electro-Fenton Using a Boron-Doped Diamond Electrode. Electrochimica Acta, 49, 4487-4496. http://dx.doi.org/10.1016/j.electacta.2004.05.006

[6] Kesraoui, A., Oturan, N., Bellakhal, N., Dachraoui, M. and Oturan, M.A. (2008) Experimental Design Methodology Applied to Electro-Fenton Treatment for Degradation of Herbicide Chlortoluron. Applied Catalysis B: Environmental, 78, 334-341. http://dx.doi.org/10.1016/j.apcatb.2007.09.032

[7] Arslan, I., Balciogul, I.A. and Bahnemann, D.W. (2000) Advanced Chemicaloxidation of Reactive Dyes in Simulated Dyehouse Effluent by Ferrioxalate-Fenton/UV-A and $\mathrm{TiO}_{2} / \mathrm{UV}$-A Processes. Dyes Pigments, 47, 207.

[8] Nam, S., Renganathan, V. and Tratnyek, P.G. (2001) Substituant Effects on Azo Dye Oxidation by the FeIII-EDTA$\mathrm{H}_{2} \mathrm{O}_{2}$ System. Chemosphere, 45, 59.

[9] Ashraf, S., Rauf, A. and Alhadrami, S. (2006) Degradation of Methyl RedFenton's Reagent and the Effect of Various Salts. Dyes Pigments, 69, 80.

[10] Zaied, M., Peulon, S., Bellakhal, N., Desmazieres, B. and Chausse, A. (2011) Studies of N-Demethylation Oxidative and Degradation of Methylene Blue by Thin Layers of Birnessite Electrodeposited onto $\mathrm{SnO}_{2}$. Applied Catalysis B: Environmental, 101, 441-450. http://dx.doi.org/10.1016/j.apcatb.2010.10.014

[11] Post, J.E. (1999) Manganese Oxide Minerals: Crystal Structures and Economic and Environmental Significance. Proceedings of the National Academy of Sciences of the United States of America, 96, 3447-3454. http://dx.doi.org/10.1073/pnas.96.7.3447

[12] Mao, L., Arihara, K., Sotomura, T. and Ohsaka, T. (2004) A Novel Alkaline Air Electrode Based on a Combined Use of Cobalt Hexadecafluoro-Phthalocyanine and Manganese Oxide. Electrochimica Acta, 49, 2515-2521. http://dx.doi.org/10.1016/j.electacta.2004.02.007

[13] Machefaux, E., Verbaer, A. and Guyomard, D. (2006) Electrochemical Synthesis of New Substituted Manganese Oxides for Lithium Battery Applications. Journal of Power Sources, 157, 443-447. http://dx.doi.org/10.1016/j.jpowsour.2005.07.035

[14] Feng, X.H., Zhai, L.M., Tan, W.F., Liu, F. and He, J.Z. (2007) Adsorption and Redox Reactions of Heavy Metals on Synthesized Mn Oxide Minerals. Environmental Pollution, 147, 366-373. http://dx.doi.org/10.1016/j.envpol.2006.05.028

[15] Chowdhury, A.N., Azam, M.S., Aktaruzzaman, M. and Rahim, A. (2009) Oxidative and Antibacterial Activity of $\mathrm{Mn}_{3} \mathrm{O}_{4}$. Journal of Hazardous Materials, 172, 1229-1235. http://dx.doi.org/10.1016/j.jhazmat.2009.07.129

[16] Lesueur, H., Czernichowski, A. and Chapelle, J. (1988) Dispositif de Génération de Plasmas Basse Température par Formation de Décharges Electriques Glissantes. French Patent No. 2639172.

[17] Fridman, A., Petrousov, R., Chapelle, J., Carnier, L.M., Czernichowski, A., Lesueur, H. and Stevefelt, J. (1994) Modèle physique de l'arc glissant. Journal de Physique III, 4, 1449-1465. http://dx.doi.org/10.1051/jp3:1994213

[18] Benstaali, B., Moussa, D., Addou, A. and Brisset, J.L. (1998) Plasma Treatment of Aqueous Solutes: Some Chemical Properties of a Gliding Arc in Humid Air. The European Physical Journal Applied Physics, 4, 171-179. http://dx.doi.org/10.1051/epjap:1998258

[19] Marouf-Khelifa, K., Abdelmalek, F., Khelifa, A., Belhadj, M. and Addou, A. (2006) Reduction of Nitrite by Sulfamic Acid and Sodium Azide from Aqueous Solutions Treated by Gliding Arc Discharge. Separation and Purification Technology, 50, 373-379. http://dx.doi.org/10.1016/j.seppur.2005.12.012

[20] Benstaali, B., Chéron, B.G., Addou, A. and Brisset, J.L. (1998) Plasma Treatment of Aqueous Solutes: Some Chemical Properties of a Gliding Arc in Humid Air. The European Physical Journal Applied Physics, 4, 939-944.

[21] Benstaali, B., Boubert, P., Chéron, B.G., Addou, A. and Brisset, J.L. (2002) Density and Rotational Temperatures Measurements of the $\mathrm{NO}$ and $\mathrm{OH}$ Radicals Produced by a Gliding Arc in Humid Air and Their Interaction with Aqueous Solutions. Plasma Chemistry and Plasma Processing, 22, 553-571. http://dx.doi.org/10.1023/A:1021371529955

[22] Imamura, A. and Hirao, K. (1979) A Molecular Orbital Approach to the Electrophilicity of H and OH Radicals. Bulletin of the Chemical Society of Japan, 52, 287-292. http://dx.doi.org/10.1246/bcsj.52.287

[23] Marouf-Khelifa, K., Abdelmalek, F., Khelifa, A., Belhadj, M., Addou, A. and Brisset, J.L. (2006) Reduction of Nitrite by Sulfamic Acid and Sodium Azide from Aqueous Solutions Treated by Gliding Arc Discharge. Separation and Puri- 
fication Technology, 50, 373-379. http://dx.doi.org/10.1016/j.seppur.2005.12.012

[24] Larabi-Gruet, N., Peulon, S. and Lacroix, A. (2008) Studies of Electrodeposition from Mn(II) Species of Thin Layers of Birnessite onto Transparent Semiconductor. Electrochimica Acta, 53, 7281-7287. http://dx.doi.org/10.1016/j.electacta.2008.03.080

[25] Shin, J.Y., Buzgo, C.M. and Cheney, M.A. (2000) Mechanochemical Degradation of Atrazine Adsorbed on Four Synthetic Manganese Oxides. Colloids and Surfaces A: Physicochemical and Engineering Aspects, 172, 113-123. http://dx.doi.org/10.1016/S0927-7757(00)00574-4

[26] Barrett, K.A. and McBride, M. (2005) Oxidative Degradation of Glyphosate and Aminomethylphosphonate by Manganese Oxide. Environmental Science \& Technology, 39, 9223-9228. http://dx.doi.org/10.1021/es051342d

[27] Zaied, M., Chutet, E., Peulon, S., Bellakhal, N., Desmazieres, B., Dachraoui, M. and Chaussee, A. (2011) Spontaneous Oxidative Degradation of Indigo Carmine by Thin Films of Birnessite Electrodeposited onto $\mathrm{SnO}_{2}$. Applied Catalysis B: Environmental, 107, 42-51. http://dx.doi.org/10.1016/j.apcatb.2011.06.035

[28] Li, H., Lee, L.S., Schulze, D.G. and Guest, C.A. (2003) Role of Soil Manganese in the Oxidation of Aromatic Amines. Environmental Science \& Technology, 37, 2686-2693. http://dx.doi.org/10.1021/es0209518

[29] Zhang, H. and Huang, C.H. (2003) Oxidative Transformation of Triclosan and Chlorophene by Manganese Oxides. Environmental Science \& Technology, 37, 2421-2430. http://dx.doi.org/10.1021/es026190q

[30] Nowack, B. and Stone, A.T. (2003) Manganese-Catalyzed Degradation of Phosphonic Acids. Environmental Chemistry Letters, 1, 24-31. http://dx.doi.org/10.1007/s10311-002-0014-3

[31] Gaillot, A.C. (2002) Caractérisation structurale de la birnessite: Influence du protocole de synthèse. Université Joseph Fourier, Grenoble, 17-78.

[32] Peulon, S., Baraize, Q. and Chausse, A. (2007) Iron Compounds Electrodeposited onto a Transparent Semiconductor: Synthesis and Characterisation by UV-Vis Spectroscopy. Electrochimica Acta, 52, 7681-7688. http://dx.doi.org/10.1016/j.electacta.2006.12.084

[33] Peulon, S. and Lincot, D. (1998) Mechanistic Study of Cathodic Electrodeposition of Zinc Oxide and Zinc Hydroxychloride Films from Oxygenated Aqueous Zinc Chloride Solutions. Journal of The Electrochemical Society, 145, 864-874. http://dx.doi.org/10.1149/1.1838359

[34] Ndjeri, M., Peulon, S., Schlegel, M.L. and Chausse, A. (2011) In Situ Grazing-Incidence X-Ray Diffraction during Electrodeposition of Birnessite Thin Films: Identification of Solid Precursors. Electrochemistry Communications, 13, 491-494. http://dx.doi.org/10.1016/j.elecom.2011.02.029

[35] Shin, J.Y. and Cheney, M.A. (2004) Abiotic Transformation of Atrazine in Aqueous Suspension of Four Synthetic Manganese Oxides. Colloids and Surfaces A: Physicochemical and Engineering Aspects, 242, 85-92. http://dx.doi.org/10.1016/j.colsurfa.2004.04.061

[36] Kang, K.H., Lim, D.M. and Shin, H.S. (2008) A Novel Solution for Hydroxylated PAHs Removal by Oxidative Coupling Reaction Using Mn Oxide. Water Science and Technology, 58, 171-178. http://dx.doi.org/10.2166/wst.2008.637

[37] Subramanian, V., Zhu, H. and Wei, B. (2006) Nanostructured $\mathrm{MnO}_{2}$ : Hydrothermal Synthesis and Electrochemical Properties as a Supercapacitor Electrode Material. Journal of Power Sources, 159, 361-364. http://dx.doi.org/10.1016/j.jpowsour.2006.04.012

[38] Joseph, J., Destaillats, H., Hung, H. and Hoffman, M. (2000) The Sonochemical Degradation of Azobenzene and Related Azo Dyes: Rates Enhancements via Fenton's Reactions. The Journal of Physical Chemistry A, 104, 301-307. http://dx.doi.org/10.1021/jp992354m

[39] Tanak, K., Padermole, K. and Hisanaga, T. (2000) Photocatalytic Degradation of Commercial Azo Dyes. Water Research, 34, 327-333. http://dx.doi.org/10.1016/S0043-1354(99)00093-7

[40] Chowdhury, A.N., Azam, M.S., Aktaruzzaman, M. and Rahim, A. (2009) Oxidative and Antibacterial Activity of $\mathrm{Mn}_{3} \mathrm{O}_{4}$. Journal of Hazardous Materials, 172, 1229-1235. http://dx.doi.org/10.1016/j.jhazmat.2009.07.129

[41] Stone, A.T. and Morgan, J.J. (1984) Reduction and Dissolution of Manganese(III) and Manganese(IV) Oxides by Organics. 1. Reaction with Hydroquinone. Environmental Science \& Technology, 18, 450-456. http://dx.doi.org/10.1021/es00124a011 